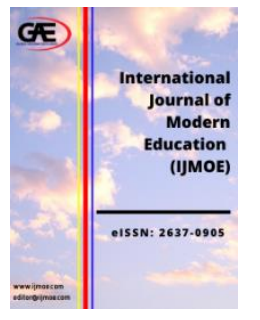

\author{
INTERNATIONAL JOURNAL OF \\ MODERN EDUCATION \\ (IJMOE) \\ www.ijmoe.com
}

\title{
PROJECT-BASED LEARNING EQUIPS UNDERGRADUATE STUDENTS WITH WORKPLACE SKILLS
}

\author{
Nur Shafiekah Sapan ${ }^{1 *}$, Siti Katijah Johari², Nurul Ain Zulhaimi ${ }^{3}$, Siti Nurul Aishah Abdul \\ Hamid $^{4}$, Siti Aishah Ramli ${ }^{5}$
}

1 Centre for the Promotion of Knowledge and Language Learning, Universiti Malaysia Sabah, Malaysia

Email: nurshafiekah@ums.edu.my

2 Centre for the Promotion of Knowledge and Language Learning, Universiti Malaysia Sabah, Malaysia

Email: sitiusuf@ums.edu.my

3 Centre for the Promotion of Knowledge and Language Learning, Universiti Malaysia Sabah, Malaysia

Email: nurulainz@ums.edu.my

4 Centre for the Promotion of Knowledge and Language Learning, Universiti Malaysia Sabah, Malaysia

Email: snaishah@ums.edu.my

5 Centre for the Promotion of Knowledge and Language Learning, Universiti Malaysia Sabah, Malaysia

Email: siti.aishah@ums.edu.my

* Corresponding Author

\section{Article Info:}

Article history:

Received date: 18.08 .2020

Revised date: 11.10 .2020

Accepted date: 25.10 .2020

Published date: 07.12.2020

\section{To cite this document:}

Sapan, N. S., Johari, S. K., Zulhaimi, N. A., Hamid, S. N. A. A., \& Ramli, S. A. (2020). Project-Based Learning Equips Undergraduate Students With Workplace Skills. International Journal of Modern Education, 2(7), 13-26.

DOI: $10.35631 / \mathrm{IJMOE.27002}$

\begin{abstract}
:
The new emerging trend for recent employment is the employers expect the university graduates to have more than academic excellence to be employed. They prefer graduates who possess soft skills such as communication skills, creativity, teamwork, management, and problem-solving. As a result, many educators are forced to change and find a new teaching and learning strategy to be incorporated in the classroom that would facilitate the students to develop both academic as well as interpersonal skills which are commonly known as soft skills. The holistic approach of Project-Based Learning (PBL) which integrates learning through working collaboratively in a project and bringing in the authentic experiences of the real world beyond the classroom walls has proven that PBL is designed to do both. The present study aimed to investigate how PBL can prepare students with related workplace skills and their perception of PBL in developing their soft skills. A set of a questionnaire is designed and administered to 77 second-year students, who are taking English for Occupational Purposes subject at Universiti Malaysia Sabah Labuan International Campus. The result of the study showed that PBL has able to equip the students with work-related skills, and by completing the projects, they were able to improve their soft skills, mainly in communication and self-confidence. Hence, the findings of the study proved that PBL is a relevant approach in a classroom to help in developing students'
\end{abstract}


soft skills.

Keywords:

Project-Based Learning, Workplace Skills, Soft Skill

\section{Introduction}

The landscape of the workforce in the 21 st century has seen significant changes which consequently affect how the organisations recruit new employees. They expected new skills to emerge due to the globalisation and advances in innovation (Rabacal, Geroso \& Oliveros, 2018). Graduates with excellent academic skills such as reading, writing, communication and listening (Faridah Musa, Norlaila Mufti, Rozmel Abdul Latiff \& Maryam Mohamed Amin, 2011) and knowledge alone are no longer sufficient for the employers as they value and seek transferable soft skills such as teamwork, critical thinking, creativity, problem-solving and management skills (Bee \& Hie, 2015; Sarkar, Overton, Thompson \& Rayner, 2016; Hart, 2019, Siti Katijah Johari, Nurul Ain Zulhaimi, Nur Shafiekah Sapan, Siti Nurul Aishah Hamid \& Siti Aishah Ramli, 2019). Moreover, graduates with excellent personal qualities such as responsible, self-confidence, adaptability, integrity, honesty and punctual are desired (Faridah Musa et al., 2011) to help to sustain the organisation's success in a long run.

The advances that ensued in the industry have posed a new challenge to the university instructors in constructing an alternative setting in preparing the students with relevant skills which would help the students to be employed after they graduate. In keeping up with the recent development, various teaching methods and strategies are implemented in the classroom to develop further and train the skills of the students. One particular teaching method that has been favoured by many educators is Project-Based Learning (PBL). Bell (2010) stated that "Project-Based learning (PBL) is an innovative approach to learning that teaches a multitude of strategies critical for success in the twentieth-first century" (p39). Besides, Boss, Larmer and Mergendoller (2013) cited in Nguyen (2017), considered PBL is an effective strategy in helping to improve the students' life skills to meet the 21st century needs. Hence, many universities have started introduced project-based learning as part of the teaching instructions to prepare better students with skills needed by the industry (Whatley, 2012). Universiti Malaysia Sabah included. With this regard, the present study designs to investigate how learning through the project can prepare the students with workplace skill.

\section{Literature Review}

In a simple term, PBL describes as learning by doing a project as learning centres on the project that the students do. PBL is not a new teaching method; instead, its origin dates back to 1980s where John Dewey, philosopher and educator, believed that students should learn through experiencing the actual activity rather than just receiving knowledge. Dewey's vision of learning is where the students viewed as a community collaborates to solve real-life situations (Nur Shafiekah Sapan, Siti Katijah Johari, Nurul Ain Zulhaimi, Siti Nurul Aishah Abdul Hamid \& Siti Aishah Ramli, 2019) and bringing in human jobs into the classroom to help the students understand the knowledge through doing the activity (Ulrich, 2016). Throughout the years, many disciplines, and from elementary schools to universities have adopted PBL in the classroom as a medium for the students to learn the concepts of selected subjects by doing a project that simulates the real-life situation which encourages them to Copyright (C) GLOBAL ACADEMIC EXCELLENCE (M) SDN BHD - All rights reserved 


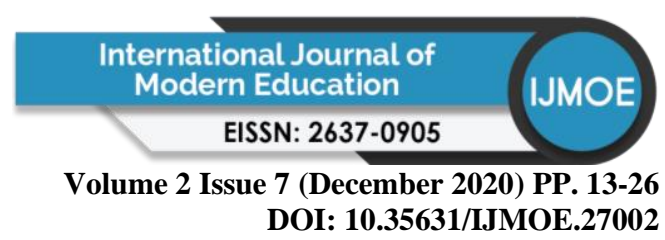

investigate, solve problems, or making decisions (Ulrich, 2016; Nur Shafiekah et al., 2019). The outcomes of project-based learning, according to Ulrich (2016), are not only limited to their academic achievements but also their skills such as cooperation, responsibility and critical thinking.

Since its inception in the 1980s, there are various definitions and criteria of PBL by numerous researchers. However, despite these differences, most of the definitions do share some of the similar features that can be summarised as an instructional approach which focuses on student-centred learning where they learn by doing a project or develop a product which based on the real-world problems over a period of time and by carrying out the project they will acquire skills such on how to investigate, solve problems, make decisions and ultimately finish with realistic products or presentations (Schneider, 2005 cited in Sadrina, Ramlee Mustapha \& Muhammad Ichsan 2018; Grant, 2002; Jones, Rasmussen, \& Moffitt, 1997; Thomas, Mergendoller, \& Michaelson, 1999 cited in Thomas, 2000; Moss \& Van Duzer, 1998). To further illustrate PBL, Stoller (2006) as cited in Du and Han (2016) listed several criteria in defining the new approach as 1) having a process and product; 2) giving students (partial ownership) of the projects; 3 ) extending over a period of time (several days, weeks or months); 4) integrating skills; 5) developing students' understanding of a topic through the integration of language and content; 6) collaborating with other students and working on their own; 7) holding students responsible for their own learning through gathering, processing, and reporting of information from target language resources; 8) assigning new roles and responsibilities to students and teacher; 9) providing a tangible final product, and 10) reflecting on both the process and the product. Due to the overlapping features in some of the definitions, the application of PBL in classroom practice is possible (Thuan, 2018).

Throughout the years, many studies have produced significant advantages of PBL, particularly in improving students' English skills. Levine (2004) cited in Thuan (2018) stated that one of the most recognised benefits of implementing PBL in the language classroom is the improve language skills. Fried-Booth also saw the use of a project in the language classroom as an opportunity for the students to use the authentic language and as a way to connect the language learned in the classroom to being used outside (Nur Shafiekah et al., 2019). According to Haines (1989), PBL gives a chance for the students to 'recycle' known language skills in a more relatively natural context while completing their project (cited in Supe \& Kaupuzs, 2015). Stoller also agreed that through PBL, it provides an opportunity for the language to be integrated naturally (Fragoulis, 2009).

The benefit of incorporating project work in the classroom is not only limited to improving students' language skills, but it also helps in developing students' skills such as teamwork, problem-solving and critical thinking. These skills are very relevant in the $21^{\text {st }}$ century as they are life-long and transferable skills that can be applied outside of the classroom (Fragoulis, 2009). Besides, Beckett (2002) stated that while working on a project, the students need to do research, develop a plan and produce reports either verbally or in writing and these activities enhance their metacognitive skills. In addition, because a project requires the students to work together, it also teaches the students skills such as solving problem, negotiation, making decisions, management and interpersonal skills (Nguyen, 2017; Kloppenborg \& Baucus 2004; Fried-Booth, 2002 and Stein 1995) and these skills are 


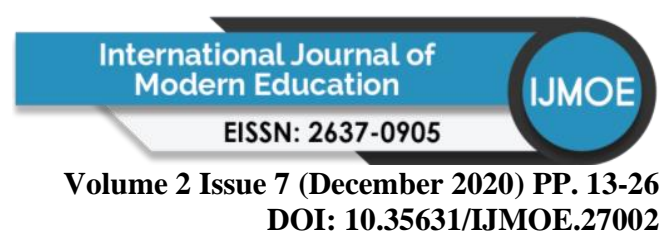

essential elements of job competence (Faridah Musa, Norlaila Mufti, Rozmel Abdul Latiff \& Maryam Mohamed Amin, 2012).

Realising the advantages of PBL in enhancing students' language skills and cultivate relevant skills needed in the workplace, many researchers and educators have started incorporated PBL into the second and foreign language classroom teaching. Firstly, Faridah Musa et al. studies in 2011 and 2012 which investigate the impact of PBL to equip the undergraduate students' with workplace skills through the Workplace Communication subject found that the projects helped the students to improve in their English communication skill through activities such as interview, negotiations and discussion. Also, by integrating projects as part of the assessment facilitates in inculcate the students with the 21 st-century workplace soft skills such as communication skill, teamwork, interpersonal skills and problem-solving. Secondly, Siti Katijah et al. (2019) examined the students' perception of PBL in the teaching of English for Employment subject. The data collected from the study showed that the students improved on their language proficiency, mostly in spoken and written communication skills. They described the tasks within the project "were positively directing towards developing the soft skills needed in their future employment life" (p.72). A study by Poonpon (2017) to the Thai undergraduate students also produced similar result where the students agreed that project-based instructions helped them practice their English skills such as reading, writing and speaking and improve their English in a real-life context. Also, Abdul Aziz Saleh Alsamani and Ayman Sabry (2016) study found that the integration of PBL into English as Specific Purposes (ESP) instructions has led to a positive impact on developing students' vocabularies. Furthermore, working on the series of tasks related to the project has created new study habits for the students such as independent, cooperative and learning outside of the classroom which also helps to develop their skills that are important in the professional world.

Based on the past studies, Thomas (2000), in his reviews on Project-Based Learning Research, concluded that PBL demonstrates as a better teaching method compared to the traditional teachings. The teaching method helps develop the students' higher-level cognitive skills by applying them in a more practical setting and "enhancing the quality of students' learning in subject matter areas" (p.37). The critical focus of PBL is for students to have opportunities to learn and acquire the skills by using real-life situations where they have to apply the skills they acquired to complete their projects. Thus, it will give them the basic ideas and initial exposure to real-world scenarios and how to use them in their future careers.

\section{Problem Statement}

Low proficiency in English and the lack of soft skills cited as the main reasons why graduates in Malaysia are unemployed. Due to the globalisation, employers are seeking graduates who can impress them not only with their great academic results but also possess excellent soft skills such as communication, collaboration, critical thinking, problem-solving, adaptability and leadership. A recent report of 2019 Emerging Jobs in Malaysia done by the global professional network LinkedIn, reported that the industry values graduates who possess both hard and soft skills. Feon Ang, the Vice-President of Talent and Learning Solutions for the Asia Pacific at LinkedIn stated that the competition in finding the right graduates to be hired is getting fierce as employers are critically selecting only those who have the right combination of hard and soft skills which would contribute to the organisation's success (The 
Volume 2 Issue 7 (December 2020) PP. 13-26 DOI: 10.35631/IJMOE.27002

News Strait Times, 2019). The educational institutions are demanded to change their existing curriculum designs which may be no longer relevant in this digital era to help prepare the coming graduates with necessary soft skills that fit the need of the 21 st-century workforce. Hence, in responding to this challenge, project-based learning is applied in the teaching of English for Occupational Purposes in Universiti Malaysia Sabah which the subject designs to equip students with Business English as well as the in-demand soft skills.

\section{Research Questions}

As past studies have proven that PBL provides positive impacts in developing relevant skills demanded in the workplace among students, the present study intends to examine how PBL can enhance students' workplace skills through the teaching of English for Occupational Purposes. The study attempted to answer the following questions:

1. How does project-based learning able to equip students with workplace skills?

2. What are their perceptions of project-based learning in facilitating their workplace skills?

\section{Methodology}

The researcher conducted the study in Universiti Malaysia Sabah Labuan International Campus (UMSLIC) to 77 low-proficiency undergraduates' students with MUET results, Band 1 (0-100), Band 2 (101-139) and Lower Band 3 (140-159). The participants consisted of 26 males and 51 females, mostly from two faculties, Faculty of International Finance Labuan (FKAL) and Faculty of Computing and Informatics (FKI). At the time of the study, all students were second-year students and enrolled in English for Occupational Purposes subject.

\section{Summary of the English for Occupational Purposes Subject}

English for Occupational Purposes (EOP) is one of the English subjects offered to proficiency students in Universiti Malaysia Sabah. It is a three hours class per week for the course of 14 weeks. The course mainly designs for students to learn the skills of effective oral and written communication at the workplace with the aim to prepare the students with English language needs and demands at the workplace. Throughout the 14 weeks, the students have the chance to go through workplace simulations where they learn to prepare, process and produce relevant documents and conduct activities which commonly practised at the workplace.

\section{Project Description}

Following the characteristics listed by Stoller (2006) earlier, figure 1 below shows the PBL framework, which implemented in the teaching of English for Occupational Purposes. 


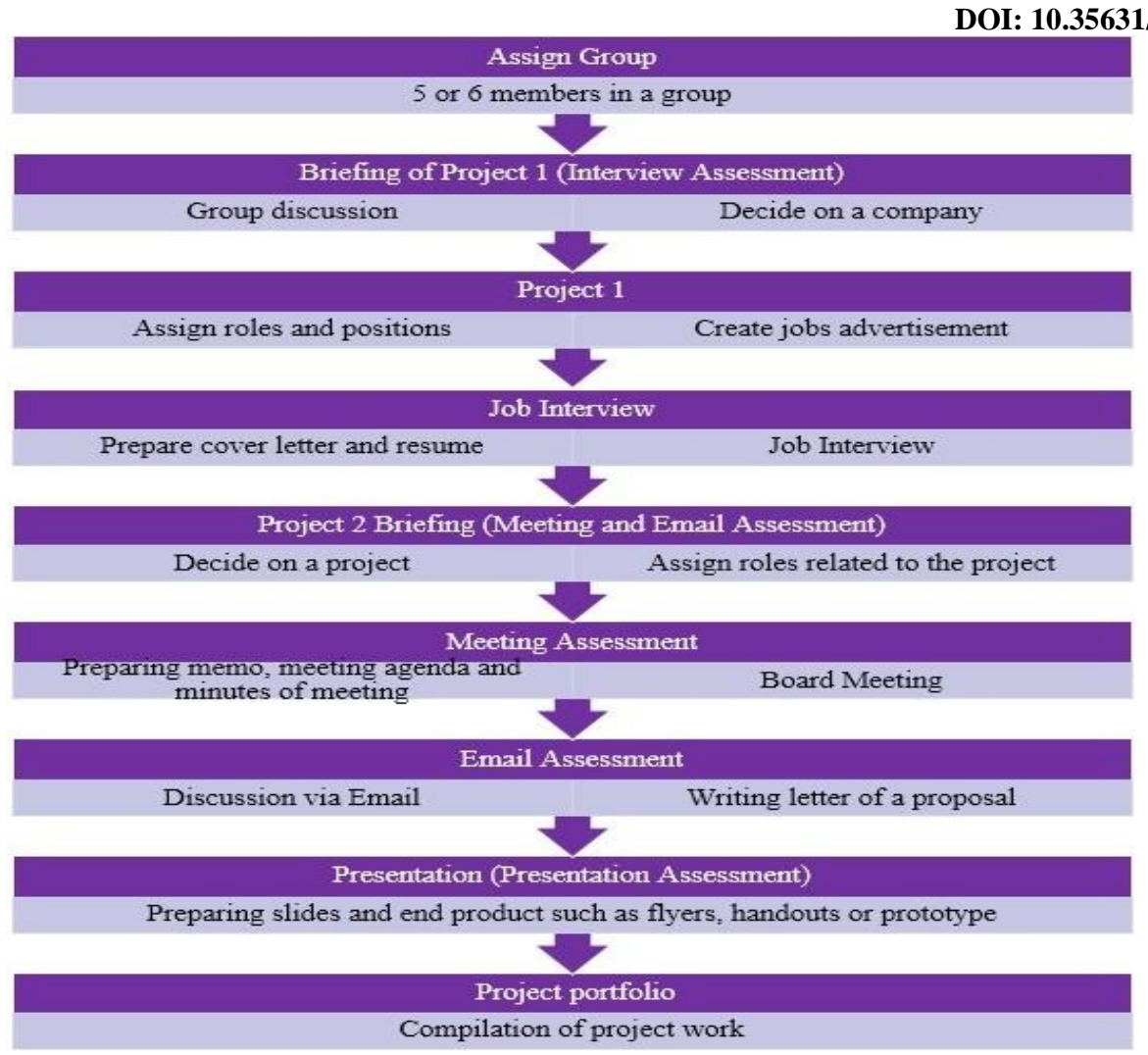

\section{Figure 1: Flowchart of Projects in English as Occupational Purposes}

The course English for Occupational Purposes introduced two related projects to students which focused on different skills in the workplace. Once the students grouped themselves into a group, lecturer briefed them on their first project, which concentrated on the interview assessment. Project 1 was mainly related to the interview assessment, where the groups were required to set up a company or a department in an established company and created five or six job vacancies in that 'company'. Each group then prepared a job advertisement which advertised the vacancies in their company for the members from different groups to apply. After decided which position they wanted to apply, each student prepared his or her cover letter and resume, which necessary for the interview assessment. In project 1, the students needed to work together in a team, discussing and making a decision related to the task given. They also went through the process of finding and applying for a job which includes writing a resume, cover letter, did research for the jobs they were applying for and lastly sat for an interview. Project 2 continued, after all of the students were 'hired' by the respective company that they applied. Each group then decided on a project for the company, such as planning an event or develop a new product or service. While completing Project 2, each group experienced business meeting, writing emails, preparing a letter of proposal and project presentation. Additionally, they also had to research to gather information, frequently meet to discuss their progress, solve problems and to make the final decision before finally presenting the finished project. 


\section{Data Collection and Instrument}

A set of a questionnaire comprised of closed and open-ended questions was administered to the participants to collect data. The questionnaire was made up of three sections include demographic, six Likert scale questions on project-based learning in general and two questions particularly asked about their teamwork and communication skills. The reasons these two skills were explicitly asked in the closed-ended questions because firstly doing the two projects in EOP mainly required the students to communicate through tasks such as interviews, meetings, discussion and presentation. Secondly, they need to be in a group in order for them to complete the project work. Hence, why these two skills were the only skills included in the closed-ended questions. In addition, 15 open-ended questions were added in the questionnaire to elicit their perceptions of using projects in the classroom and other workplace skills they acquired while finishing those projects. Before distributing the survey, researcher briefed the participants on the purpose of the study and their participation was voluntary. The data from the closed-ended questions were analysed using frequency analysis while the students' responses from the open-ended questions were analysed using thematic analysis. According to Maguire and Delahunt (2017), thematic analysis refers to the "process of identifying patterns or themes within qualitative data" (p.3352). The thematic analysis allows the researcher to identify what is significantly related to a topic or research question being explored (Braun \& Clarke, 2012). The students' responses were analysed and coded to search for repeating pattern or themes. The coded data then grouped and labelled according to the theme which provide answers to the two research questions in this study; 1) how does PBL able to equip students with workplace skills and 2) the students' perception of PBL in facilitating their workplace skill.

\section{Result and Discussion}

\section{Research Question One: How does Project-Based Learning able to Equip Students with Workplace Skills?}

One of the main objectives of English for Occupational Purposes is to prepare the students with workplace skills which would benefit them in their future workplace. Hence, the implementation of projects as part of the teaching methods is to expose students with work environment throughout the semester.

Project-Based Learning Equips Students with Teamwork Skill

Table 1: PBL Equips Students with Teamwork Skill

\begin{tabular}{|c|c|c|c|c|c|c|}
\hline & Statement & $\begin{array}{l}\text { Strongly } \\
\text { Disagree }\end{array}$ & Disagree & Neutral & Agree & $\begin{array}{l}\text { Strongly } \\
\text { Agree }\end{array}$ \\
\hline 13 & $\begin{array}{l}\text { The group project has helped } \\
\text { me develop my ability to work } \\
\text { as a team/group member }\end{array}$ & $\begin{array}{l}0 \\
(0 \%)\end{array}$ & $\begin{array}{l}0 \\
(0 \%)\end{array}$ & $\begin{array}{l}0 \\
(0 \%)\end{array}$ & $\begin{array}{l}28 \\
(36.4 \%)\end{array}$ & $\begin{array}{l}49 \\
(63.6 \%)\end{array}$ \\
\hline
\end{tabular}

Table 1 above presents the result of teamwork. Item no.13 in the questionnaire was explicitly asked the respondents on teamwork. Surprisingly, all respondents agreed that doing a project in the classroom has helped them to develop their ability in working as a team. The same 
Volume 2 Issue 7 (December 2020) PP. 13-26

DOI: 10.35631/IJMOE.27002

result was also supported through the responses given by the participants through the openended questionnaire.

"I have developed my teamwork skill" -R68

"The most important thing I have learned is how to make strong relationship between group members" -R70

"I learned how to be a good teammate" -R42

"I can learn how to work in group effectively and tolerate with each other by sharing ideas and opinions" -R51

"My biggest improvement is teamwork. We help each other when we have problem" R33

Report by QS Global Skills Gap in the 21st century, which published in 2018 mentioned teamwork as one of the top three workplace skills that were sought after by employers. Through the responses, it is evident that learning via projects has able to improve the students' collaboration skill. Throughout the course, the students had to complete their two projects in a group. The students, hence, were compulsory to form their group, manage the project, make decisions and solve a problem. Nguyen (2017) stated that one possible reason their teamwork skill has improved is that the students were mandatory to work together where they need to meet each other regularly to discuss with each other to complete their project. According to Powel and Weenk (2003) cited in Alves et al. (2012), working as a team takes almost $50 \%$ of the learning activity, which would significantly contribute to improving their teamwork.

\section{Project-Based Learning Equips Students with Communication Skill}

One notable result of project-based learning would be communication skill. As shown in Table 2 below, a total of $96.1 \%$ agreed while completing the projects; their communication skill enhanced.

Table 2: PBL Equips Students with Communication Skill

\begin{tabular}{|c|c|c|c|c|c|c|}
\hline & Statement & $\begin{array}{l}\text { Strongly } \\
\text { Disagree }\end{array}$ & Disagree & Neutral & Agree & $\begin{array}{l}\text { Strongly } \\
\text { Agree }\end{array}$ \\
\hline 9 & $\begin{array}{l}\text { Working on this project has } \\
\text { helped to improve my } \\
\text { communication skill }\end{array}$ & $\begin{array}{l}0 \\
(0 \%)\end{array}$ & $\begin{array}{l}0 \\
(0 \%)\end{array}$ & $\begin{array}{l}2 \\
(2.6 \%)\end{array}$ & $\begin{array}{l}32 \\
(41.6 \%)\end{array}$ & $\begin{array}{l}42 \\
(54.5 \%)\end{array}$ \\
\hline
\end{tabular}

The ability to communicate well to colleagues, managers and customers remain as a critical skill that the graduate should have. Organisations value employees who can speak confidently, and it is a skill that sets candidates apart from others when applying for a job. Implementing projects as part of their assessment would immensely benefit the students, particularly in their communication skill. Moreover, the students realised that by having continuous interactions about the project such as discussion, meetings, and presentation not only help to develop their communication skill but simultaneously improve their English.

"In this project we have meeting so we need to more communicate with the people.

That is why it really help me to improve my communication skill" - R3 


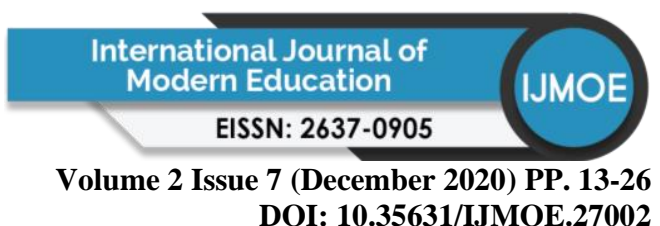

"We are given the chance to speak in English..so student can improve their speaking skill in English" - R6

"This project forced us to speak in English with groupmates. That is a point that forced us to learn and speak in English" - R64

"It can enhance my communications skill" -R68

"My biggest area of improvement is communication skills because this time we need to communicate a lot to finish the project successfully" - R70

In Malaysia, poor command of English skill primarily in speaking is among the main reason for the high numbers of graduates are unemployed (Nur Shafiekah et al., 2019). However, it is apparent from these responses that extensive communication between group mates and instructors facilitate in improving their ability to speak in English. The result of this finding parallel with the studies done by Faridah Musa et al. (2011), Poonpon (2017), Essein (2018), Siti Katijah et al. (2019) and Nur Shafiekah et al. (2019) where numerous speaking activities have compelled them to use English while completing the task thus improved their ability in English proficiency. Moreover, Hedge (1993) cited in Du and Han (2016) stated that the project consists of several small activities, also integrates language skills such as the use of authentic English language materials. Throughout the course, students exposed to workplace environments and they had the opportunity learning and referring to authentic materials, for instance, actual resume, minutes of a meeting, interview to the extent of using those workplace expressions and language in their assessments.

\section{Project-Based Learning Equips Students with Management Skill}

The students also indicated that doing projects have helped them to plan and manage their time correctly. Management skill is another attribute that is important for the organisation as good management would ensure the success of the organisations. Before the students work on their projects, the first thing that they would do was to have careful planning on how they were going to carry out the project, delegate task among the members equally to ensure that they achieve the aim of their project. These can be seen from the following responses,

"I have learned is how to manage myself in doing this project" - R77

"The most important thing I have learned is how I managed my time to settle every task that has given" -R54

"I learn something new about how to handle this kind of project step by step," -R57

"I have learned to finish all the works on time before deadlines"-R33

A similar finding was also found in a study by Nguyen (2017). She stated one of the noticeable skills the students improved after fulfilled their two projects was timemanagement. To complete the project on time, they had no choice but to finish all assigned task within the time given. In this course, every task given to them was arranged sequentially, which slowly build-up to help them complete their project. The due date for each assessment was mostly one week, so they have to carefully plan how to finish the tasks on time before getting another task. As the idea of the project originated from the students themselves, therefore the sense of responsibility was heightened as they tried to finish the project. Stoller (2006) in his definition of PBL, stated that the projects gave the students sense of ownership which allow them to learn to organise their projects themselves (cited in Du \& Han (2016)). 


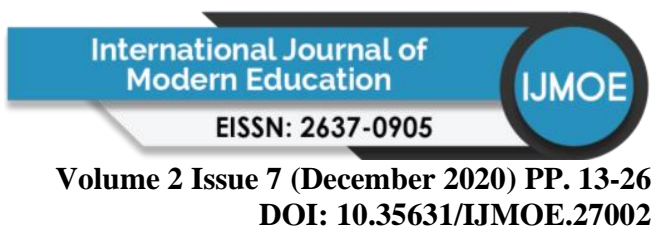

Project-Based Learning Equips Students with the Problem-Solving Skill

The following responses have demonstrated that the students have acquired problem-solving skill through project-based learning.

"The most important thing I learned is to handle and solve problem" -R3

"facing all the problems and find solution with other groupmates"-R11

"I have learned how to find solutions quickly to solve a problem"-R59

"I can use the way to generate alternatives to solve the problem"-R67

In the fast-changing work environment, challenges come in different forms, and sometimes they come one after another; consequently, employees are expected to provide intelligent solutions within a short time. By implementing projects in the classroom mainly in this course which designed to prepare them before entering the industry, were perfect as they were able to experience the authenticity of the project and the problems that came with it commonly happened in the workplace. The students went through a real-like workplace process where they have to deal with many sorts of issues ranging from member's participation, communication, conflict, finding resources and time management. The finding resonates with studies conducted by Faridah Musa et al. (2012) and Pinho-Lopes and Macedo (2014), Rany Apriyani et al. (2019) where the implementation of projects as part of the teaching methodology has shown a significant increase in the students' problem-solving skill. According to Katz and Chard (2000), as cited in Du and Han (2016), PBL is a practical approach in developing student's problem-solving skill where it allows the students to provide solution and seek answers in the context of real and meaningful life.

\section{Research Questions Two: What are Their Perceptions of Project-Based Learning in Facilitating Their Workplace Skills?}

In section $\mathrm{C}$ of the questionnaire, students wrote their opinions on the implementations of projects in the course and $80 \%$ of the respondents agreed that completing the projects have benefited them so much specifically in preparing themselves for their future employment.

"This is because the project related with the future work" - R45

"The skills can be used when dealing in the real world and it shows me how I need to prepare sooner" -R18

"I believe what I learned in this project will help me in my future career" -R34

As the findings showed, the course has exposed them with many workplace skills which are useful for them as simple as finding jobs to match their qualifications, abilities and skills. As most of the students have no prior working experience, it is vital for them to know how to seek profession which is relevant to their knowledge and skills. Besides, the project and the course overall has also made them realise that they need to develop a variety of skills which are crucial in the industry such as preparing a resume, writing work-related documents, and pass in the interview.

"It is positive since I learn how to apply a new job, interview, make video resume, meeting and so on. It is very helpful for my future career" -R77

"I will remember the format of the cover letter, resume, meeting so that I can use it in my future career" -R34 


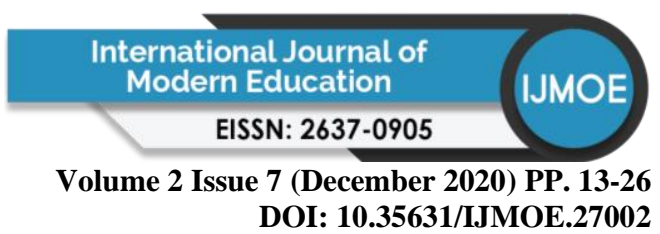

"When we do part of the meeting agenda, meeting notice and proposal, it will help us to recognise some new formal words that used in these particular documents" -R34

Moreover, the tasks within the projects also provide them with an opportunity to feel as if they were in the real work environment, for instance, during the interview session. Before the interview, they had to prepare their resume and researched job they applied for as well as the chance to assume the role of interviewer where they interviewed their classmates. These simulations also excite them to participate in the activities where they can experience the feeling of being an employee.

"I like it because it help me on how to succeed in interview session, enclosed us with real work scenario and much more," -R5

"This project can let me feel the realistic of being an employee," -R55

"This setting enables us have a great overview of how a real job scope should be and how to prepare for the future," -R64

Moss and Van Duzer (1998) and Thomas (2000) in their definition of PBL stated that the realisticity of the projects is the essence that made PBL being favoured by many educators to teach concepts through practical application.

\section{Conclusion}

The present study aimed to investigate how project-based learning facilitates in equipping students' with workplace-related skills. A majority of the students agreed that PBL has positive impacts in preparing them for the future. Besides, by doing the projects, the students were able to equip themselves with the skills in a short time due to the hands-on learning approach. Due to the nature of the projects, the students have to collaborate, sharing opinions and finding solutions to the problems they faced, which at the same time help to develop their communication, creativity and teamwork. The students mentioned explicitly that working on the projects have increased their teamwork, communication, problem solving and management skills in which these skills are among the top skills demanded by the organisations in graduates. In addition, the connection of real-world with the project allows students to gain real-life experiences beyond the classroom where they have to solve realistic and contextualised problems (Blumenfeld et al. (1991) in Vogler et al. (2018). The results also indicated that the activities which feature the real-work environment had helped them to prepare themselves for the future. The findings of the study showed that PBL is practical instruction for teaching workplace skills. PBL offers the opportunity for the students to learn through the same approach as they would experience later in their career (Essein, 2018). As noted earlier that the recruiters in the industry are no longer recruit graduates based on their academic qualification alone but rather putting more emphasis on their workplace skills which would assist in the success of the organisation. Thus, it is crucial to instil the right skills to the students from earlier on as the world keeps on advancing to a more competitive setting. According to Bell (2010), "by implementing PBL, we are preparing our students to meet the twenty-first century with preparedness and a repertoire of skills they can use successfully" (p.43). Although the present study has shown positive results in equipping students with workplace skills, the results could not be generalised as the results only reflect low-proficiency students from UMS Labuan International Campus branch. A more significant sample covering students from three branches of UMS should be included to validate the findings. Albeit the effectiveness of project-based learning in preparing students Copyright $\odot$ GLOBAL ACADEMIC EXCELLENCE (M) SDN BHD - All rights reserved 
Volume 2 Issue 7 (December 2020) PP. 13-26

DOI: 10.35631/IJMOE.27002

with relevant workplace skills, careful planning of the project should be done by instructors to ensure the projects can achieve its objective in providing our students with relevant skills demanded in the $21^{\text {st }}$-century workplace.

\section{Acknowledgement}

This study was funded by UMSGrant, Center for Research and Innovation, Universiti Malaysia Sabah. (Grant No: SBK0387-2018)

\section{References}

Abdul Aziz Saleh Alsamani \& Ayman Sabry Daif-Allah. (2016). Introducing project-based instruction in the Saudi ESP classroom: A study in Qassim University. English Language Teaching, 9(1). 51-64. Retrieved from http://www.ccsenet.org/journal/index.php/elt/article/view/55425

Alves, A. C., Mesquita, D., Moreira, F., \& Fernandes, S. (2012). Teamwork in project-based learning: Engineering students' perceptions of strengths and weaknesses. International Symposium on Project Approaches in Engineering Education, 23-32. Retrieved from https://repositorium.sdum.uminho.pt/bitstream/1822/36308/1/2012\%20Paper\%20PAE E2012\%20AA\%2BDM\%2BFM\%2BSF.pdf

Bell, S. (2010). Project-based learning for the 21st Century: Skills for the future. The Clearing House: A Journal of Educational Strategies, Issues and Ideas, 83(2), 39-43. doi:10.1080/00098650903505415

Beckett, G.H. (2002). Teacher and student evaluations of project-based instruction. TESL Canada Journal, 19(2), 52-66.

Bee, O. K., \& Hie, T. S. (2015). Employers' emphasis on technical skills and soft skills in job advertisements. The English Teacher, 44(1), 1-11.

Braun, V. \& Clarke, V. (2012). Thematic analysis. In H. Cooper, P. M. Camic, D. L. Long, A.T. Panter, D. Rindskopf, \& K. J. Sher (Eds), APA handbook of research methods in psychology, Vol. 2: Research designs: Quantitative, qualitative, neuropsychological, and biological (pp. 57-71). Washington, DC: American Psychological Association.

Du, X., \& Han, J. (2016). A literature review on the definition and process of project-based learning and other relative studies. Creative Education, 07(07), 1079-1083. doi:10.4236/ce.2016.77112

Essien, A. M. (2018). The effects of project-based learning on students' English languageability. The 2018 International Academic Research Conference, 438-443. Retrieved from http://www.ijbtsjournal.com/images/main_1366796758/66)\%20VI18-1142_Full\%20PaperAbigail\%20Melad\%20Essien.pdf

Faridah Musa, Norlaila Mufti, Rozmel Abdul Latiff, Maryam Muhamed Amin. (2011). Project-based learning: Promoting meaningful language earning for workplace skills. Procedia - Social and Behavioral Sciences, 18, 187-195. doi:10.1016/j.sbspro.2011.05.027

Faridah Musa, Norlaila Mufti, Rozmel Abdul Latiff, Maryam Muhamed Amin.(2012). Project-based learning (PjBL): Inculcating soft skills in 21st century workplace. Procedia - Social and Behavioral Sciences, 59, 565-573. doi:10.1016/j.sbspro.2012.09.315

Fragoulis, I. (2009). Project-based learning in the teaching of English as a foreign language in Greek primary schools: From theory to practice. English Language Teaching. 2(3), 
113-119.

Retrieved

from

http://www.ccsenet.org/journal/index.php/elt/article/download/2739/3286

Fried-Booth, D., L. (2002). Project work (2nd ed.). New York: Oxford University Press.

Grant, M. M. (2002). Getting a grip on project-based learning: Theory, cases and recommendations. Meridian: A Middle School Computer Technologies Journal A Service Of NC State University, Raleigh, 5(1). Retrieved from http://www.ncsu.edu/ meridian/win2002 /514/project- based.pdf.

Hart, J. (2019). Interdisciplinary project-based learning as a means of developing employability skills in undergraduate science degree program. Journal of Teaching and Learning for Graduate Employability, 10(2), 50-66.

Hazlina Aziz. (2018, October 3). Graduate skills gap. New Straits Times. Retrieved from https://www.nst.com.my/

Kloppenborg, T. J. \& Baucus, M. S. (2004). Project management in local nonprofit organisations: Engaging students in problem based learning. Journal of Management Education. 28, 610 - 630.

Maguire, M. \& Delahunt, B. (2017). Doing a thematic analysis: A practical, step-by-step guide for learning and teaching scholars. All Ireland Journal of Teaching and Learning in Higher Education, 8(3). 3351-33514. Retrieved from http://ojs.aishe.org/index.php/aishe-j/article/view/335

Moss, D. \& Duzer, C.V. (1998). PBL for adult English language learners. ERIC Digest.Retrieved from https://files.eric.ed.gov/fulltext/ED427556.pdf

Nguyen, T. T. (2017). Developing important life skills through project-based learning: A case study. The Normal Lights, 11(2), 109-142. Retrieved from https://pdfs.semanticscholar.org/d85d/6dbedf4ebf63c425fca4c929441857409b9b.pdf

Nur Shafiekah Sapan, Siti Katijah Johari, Nurul Ain Zulhaimi, Siti Nurul Aishah Abdul Hamid \& Siti Aishah Ramli. (2019). Project-based learning and its effect on students' English skills. International Journal Of Education And Pedagogy, 1(2), 73-85. Retrieved from http://myjms.moe.gov.my/index.php/ijeap/article/view/7831

Pinho-Lopes, M., \& Macedo, J. (2014). Project-based learning to promote high order thinking and problem solving skills in geotechnical courses. International Journal of Engineering Pedagogy (iJEP), 4(5), 20. doi:10.3991/ijep.v4i5.3535

Poonpon, K. (2017). Enhancing English skills through project based learning. The EnglishTeacher, 40, 1-10. Retrieved from https://journals.melta.org.my/index.php/tet/article/view/258

Rabacal, J. S., Geroso, J. S., \& Oliveros, J. A. (2018). Developing students 21 st centuryskills using project based learning. Asia Pacific Journal of Multidisciplinary Research, 6(2), 47-53. Retrieved from http://www.apjmr.com/wp-content/uploads/2018/06/APJMR2018.6.2.2.06.pdf

Rany Apriyani, Taufik Ramlan Ramalis, \& Irma Rahma Suwarma. (2019). Analysing student's problem solving abilities of direct current electricity in STEM-based learning. Journal of Science Learning, 2(3), 85-91. doi:10.17509/jsl.v2i3.17559

Rozana Sani. (2019, February 20). Demand for soft skills in the workplace. New Straits Times. Retrieved from https://www.nst.com.my/

Sadrina, Ramlee Mustapha \& Muhammad Ichsan. (2018). The evaluation of project-based learning in Malaysia: Propose a new framework for polytechnic system. Jurnal Pendidikan Vokasi,2(8), 143-150. Retrieved from https://journal.uny.ac.id/index.php/jpv/article/view/19100 
Volume 2 Issue 7 (December 2020) PP. 13-26

DOI: 10.35631/IJMOE.27002

Sarkar, M., Overton, T., Thompson, C., \& Rayner, G. (2016). Graduate employability: Views of recent science graduates and employers. International Journal of Innovation in Science and Mathematics Education, 24(3), 31-48. Retrieved from https://openjournals.library.sydney.edu.au/index.php/CAL/article/view/11043

Siti Katijah Johari, Nurul Ain Zulhaimi, Nur Shafiekah Sapan, Siti Nurul Aishah AbdulHamid \& Siti Aishah Ramli. (2019). Authentic learning experience: Engaging students into a "real-life' project in an English classroom. ELSA $2019 e$ PROCEEDINGS, 65-79.

Stein, S. (1995). Equipped for the future: A customer-driven vision for adult literacy and lifelong learning. Washington, DC: National Institute for Literacy.

Supe, O., \& Kaupuzs, A. (2015). The effectiveness of project- based learning in the acquisition of English as a foreign language, Society Integration Education, 2, 211218. doi: http: //dx.doi.org/10.17770/ sie2015vol2.458

Thomas, W. J. (2000). A review of research on project-based learning. California: TheAutodesk Foundation. from http://www.bobpearlman.org/BestPractices/PBL_Research.pdf

Thuan, P.D. (2018). Project-based learning: From theory to EFL classroom practice. Proceedings of the $6^{\text {th }}$ International Open TESOL Conference 2018. 327-339. Retrieved from https://www.academia.edu/38231979/Project_Based_Learning_From_Theory_to_EF L_Classroom_Practice_pdf

Ulrich, C. (2016). John Dewey and the project-based learning: Landmarks for nowadays Romanian education. Journal of Educational Sciences \& Psychology, 6(68), 54-60.

Vogler, J. S., Thompson, P., Davis, D. W., Mayfield, B. E., Finley, P. M., \& Yasseri, D. (2017). The hard work of soft skills: Augmenting the project-based learning experience with interdisciplinary teamwork. Instructional Science, 46(3), 457-488. doi:10.1007/s11251-017-9438-9

Whatley, J. (2012). Evaluation of team project based learning module for developing employability skills. Issues in Informing Science and Technology, 9, 75-91. 